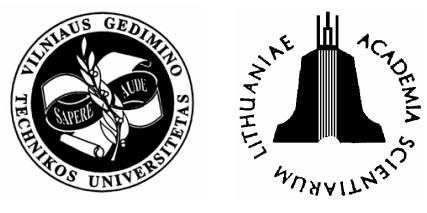

\title{
ANALYSIS OF THE DYNAMICS OF WALKING DISTANCES TO PUBLIC TRANSPORT ROUTES AND ITS INFLUENCE ON HOUSING PRICES
}

\author{
Rasa Ušpalytè-Vitkūniené ${ }^{1}$, Marija Burinskiené ${ }^{2}$ \\ Dept of Urban Engineering, Vilnius Gediminas Technical University, \\ Saulètekio al. 11, LT-10223 Vilnius, Lithuania. \\ E-mail: ${ }^{1}$ Rasa.uspalyte@ap.vtu.lt, ${ }^{2}$ Marija.Burinskiene@ap.vtu.lt \\ Received 29 Aug 2005; accepted 15 Nov 2005
}

\begin{abstract}
Accessible public transport system is an essential indicator that guarantees equal travelling opportunities for all people. Scientific research has revealed that poor accessibility to public transport mostly affects low-income people and the elderly. People from these groups have fewer opportunities to reach education institutions, working places, or health institutions. Access to public transport routes is among public transport indicators that are important for these social groups of people. An analysis reveals that during the last six years, from 1998 to 2004, access to public transport increased on average by $1,28 \%$ in the district area.

The analysed indicators of population density, working density, ratio of built up territories and green areas, accessibility of the public transport, density of routes in the area in question, and the distance to the centre revealed that the accessibility to public transport also has a significant influence on the price of housing, especifically for the above social group.
\end{abstract}

Keywords: public transport, transport system, accessibility, housing price.

\section{Introduction}

An accessible public transport system is an essential indicator that guarantees equal travelling opportunities for all people. In future, public transport accessibility should attach more significance when working out solutions to land use and transport. In cities, only planning residential and business territories alongside the transport system solutions, and including the development of the public transport system can develop a sustainable communication system $[1,2]$.

In 2001 and 2003, Hine J. and Mitchell F. carried out research in Great Britain, which revealed that poor public transport accessibility has the greatest impact on low-income and older people. People from these groups have fewer opportunities to reach education institutions, working places or health institutions [3, 4].

Communication planning is inseparable from social, demographic and economic interests of residents, and thus when planning the town's transport system, an analysis of these processes should be included. Private cars and the public transport are the main competitors in the urban transport system. The main task of scientists Mackett R. L., Hensher D. A. and Gibbons' E., research was to achieve the aim so that people would leave their cars and make use of public transport at least for short trips, and state that passengers should be provided with a developed, efficient, attractive and easily accessible public transport system. This system should be developed in the residential areas of the city, so that the integrity of the public transport system is maintained. [1, 5-7]. Division of the territory that is being planned into transport districts enables planners to have a more detailed analysis and evaluation of the situation in individual parts of the town. In communication planning the central focus is given to finding out characteristics of the street network and the communication system of the public transport system [8].

People's needs for public transport depends not only on the distribution of working, studying and leisure-time places and their transport mobility but also on the infrastructure of the public transport and the supply of communication, as well as on the maintenance characteristics of motor vehicles [9, 10]. The European Union Standard (EN13816: 2002), which was also approved in Lithuania, contains a system of functional and technical quality indicators of the urban public transport [11]:
1. Availability
5. Care for passengers
2. Accessibility
6. Comfort
3. Information
7. Safety
4. Time
8. Environment

The goal of this article is, by analyszing the public transport of Vilnius, to find out whether during the last 6 years, the network of the public transport routes was developed in the best direction with regard to its accessibility and the satisfaction of residents' needs. With that regards, the following tasks were set:

- To analyse whether the direction of changes in the network of the public transport routes was correct in terms of accessibility; 
- To analyse how accessibility of public transport is linked to the population's density in transport districts;

- What is the impact of accessibility of the public transport on housing prices?

\section{Methods for the calculation of public transport accessibility}

Accessibility of the districts of Vilnius was researched in a graphic-analytical way with a view to analysing the dynamics of accessibility of public transport in 1998-2004. A maximum distance from the stopping place of the public transport was chosen by the following the technical regulation, ie "Communication systems of towns, small towns and villages", according to which Vilnius is categorised as a city. Thus, the minimal density of the public transport network must be such that the maximum walking distance to public transport would not exceed $500 \mathrm{~m}$ in the area of high-rise buildings and $600 \mathrm{~m}$ in the area of low-rise buildings [12]. By overlooking the height of built-up districts of Vilnius, $90 \%$ of the districts are of high-rise building-up, it can be seen that public transport stops should be located at a distance of at least $500 \mathrm{~m}$.

With the help of the software ArcView, the whole territory of Vilnius and its suburbs, which was the researched territory, was divided into transport districts. [8] The boundaries of the accessibility of the public transport in Vilnius was assumed to be at a distance of 500 meters from the public transport stopping places and at a distance of $500 \mathrm{~m}$ from the routes of private public transport (Fig 1).

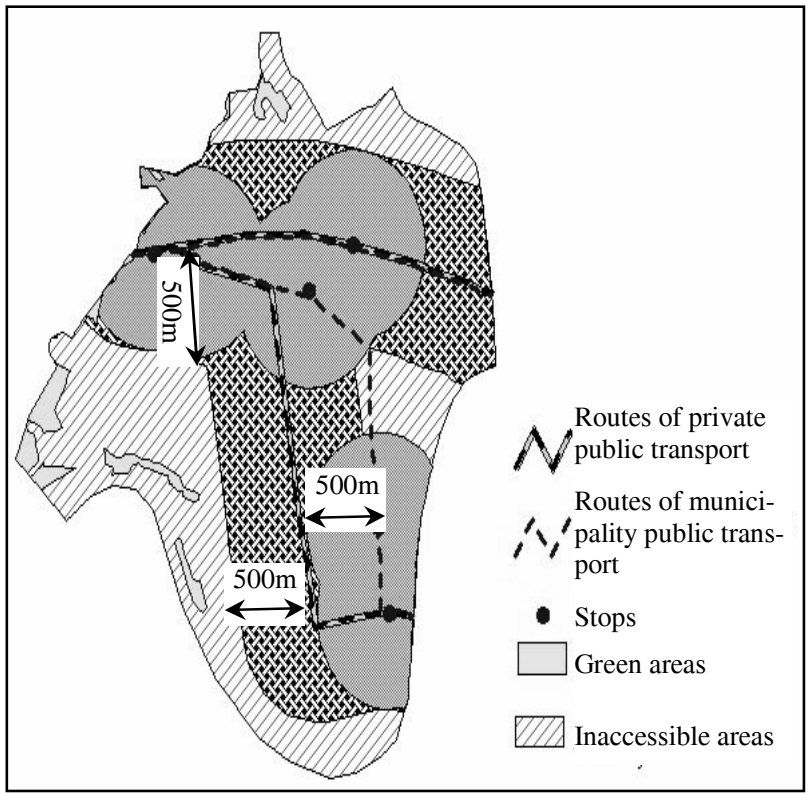

Fig 1. Principal scheme of the calculation of accessible territories

To have a more specific assessment of the position of these districts in the city structure, the districts were divided into 3 zones:

1. The central part that covers districts that are within $5 \mathrm{~km}$ from the centre;
2. The middle part of the city that covers districts that are situated within 5 to $10 \mathrm{~km}$ from the centre;

3. The peripheral part of the city that covers districts that are situated more than $10 \mathrm{~km}$ from the centre.

The accessibility was assessed as the ratio of the areas reached by public transport of the district in question, excluding green areas within the districts. Districts, in which accessible areas account for up to $20 \%$ are areas inaccessible by public transport routes, from 20 to $40 \%-$ little accessibility, 40 to $60 \%$ - accessible, 60 to $80 \%$ well accessible and from 80 to $100 \%$, are evaluated as fully accessible by the public transport routes.

\section{Accessibility of public transport routes in Vilnius in 2004}

Based on the work previously carried out by the Dept of Urban Engineering, Vilnius is divided into three zones - central, medial, and peripheral. These zones should be separately served by public transport too. The central part comprises of historically formed districts of the city, and thus streets are not adjusted to a large transport flow.

The middle zone of the city surrounds its core where most residential and some industrial areas are situated; there, the street network is favourable for public transport communication, though, street capacity is too low for car communication. Street density of the peripheral zone of the city, which covers low-rise built-up areas, e g garden communities, and city districts that have been connected to Vilnius, is not very high but with a low population density it enables planners to choose among all desirable modes of transport [13].

Public transport routes accessibility analysis of the data from 2004 shows that the access to the Vilnius' central zone is very good and its accessibility fluctuates between 80 and $100 \%$. The network of urban public transport has been formed by taking into regard the needs of residents; thus in the central districts of Vilnius bus stops are situated closer to each other due to a great number of working places and attraction objects. Supermarkets, prestigious stores and recreation centres are situated in these districts (Fig 2).

The highest flows of public transport passengers, whose final destination is not necessarily in the centre, are observed in the central districts of the city; so, in order to avoid an overload of public transport stops their key points of change to another transport are denser. Density of stops of public transport in the central districts of cities could serve as a supplementary part of the Park\&Ride system, which would facilitate reaching abundant attraction objects in the central part of the town without any help from private transport means and would reduce flows of transport in those areas [14].

In the middle part of Vilnius, where districts are 5$10 \mathrm{~km}$ away from the centre of the city, the lowest public transport route's accessibility indicator is observed only in Medžiakalnis district. In this district, the urbanised areas account for $5,7 \%$ of the total territory of the district. 


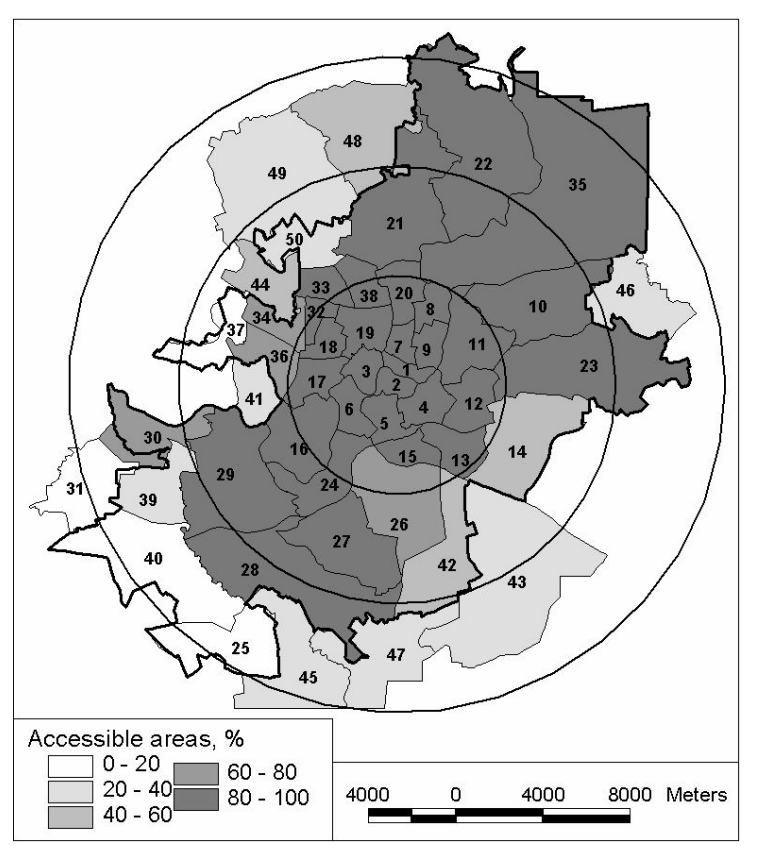

Fig 2. Accessibility of the public transport of Vilnius city in 2004

Table 1. Dependence of accessibility on population density

\begin{tabular}{|c|c|c|c|c|c|c|c|}
\hline 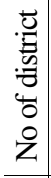 & $\begin{array}{l}\stackrel{\Xi}{\Xi} \\
\text { 乙 }\end{array}$ & 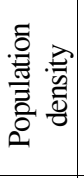 & 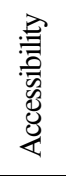 & 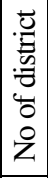 & $\begin{array}{l}\stackrel{\mathscr{I}}{\overparen{Z}} \\
\text { Z }\end{array}$ & 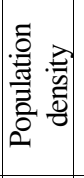 & 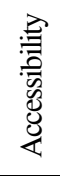 \\
\hline 32 & Justiniškès & 186 & 100 & 47 & Juodšiliai & 8 & 37 \\
\hline 9 & Žirmūnai II* & 160 & 100 & 10 & Dvarčionys & 6 & 85 \\
\hline 17 & Karoliniškès* & 133 & 100 & 45 & Pagiriai & 6 & 26 \\
\hline 38 & Fabijoniškès* & 116 & 100 & 35 & Valakupiai & 5 & 100 \\
\hline 19 & Šeškinè* & 96 & 100 & 26 & Kirtimai & 4 & 79 \\
\hline 15 & Naujininkai* & 86 & 100 & 44 & Buivydiškès & 4 & 52 \\
\hline 5 & Naujamiestis* & 81 & 100 & 50 & Tarandè & 3 & 38 \\
\hline 6 & Vilkpèdè* & 81 & 100 & 43 & Nemezžis & 3 & 36 \\
\hline 18 & Viršuliškès* & 79 & 100 & 48 & Riešè & 3 & 58 \\
\hline 4 & Senamiestis* & 76 & 100 & 14 & Pavilnys & 2 & 55 \\
\hline 33 & Pašilaičiai & 74 & 91 & 27 & Užusienis & 2 & 83 \\
\hline 7 & Šnipiškès* & 72 & 100 & 29 & Gariūnai & 2 & 100 \\
\hline 16 & Lazdynai & 69 & 100 & 28 & A. Paneriai & 2 & 88 \\
\hline 11 & Antakalnis* & 66 & 100 & 49 & Avižieniai & 2 & 34 \\
\hline 8 & Žirmūnai* & 66 & 100 & 46 & Galgiai & 2 & 21 \\
\hline 2 & Centras II* & 53 & 100 & 40 & Trakų Vokė & 2 & 16 \\
\hline 3 & Žvėrynas* & 53 & 95 & 34 & Pilaite II & 1 & 62 \\
\hline 20 & Baltupiai* & 53 & 100 & 41 & Salotė & 1 & 33 \\
\hline 1 & Centras I* & 39 & 100 & 37 & Medžiakalnis & 1 & 3 \\
\hline 36 & Pilaité & 28 & 72 & 42 & Kuprijoniškès & 1 & 50 \\
\hline 12 & Belmontas* & 24 & 100 & 30 & Grigiškės & 1 & 77 \\
\hline 24 & Ž. Paneriai & 24 & 88 & 39 & Gureliai & 1 & 24 \\
\hline 13 & Rasos* & 18 & 55 & 22 & Verkiai & 1 & 100 \\
\hline 23 & Naujoji Vilnia & 16 & 87 & 25 & Vaidotai & 1 & 17 \\
\hline 21 & Santariškès & 8 & 86 & 31 & Lentvaris & 1 & 13 \\
\hline
\end{tabular}

* Districts that are no more than $5 \mathrm{~km}$ away from the centre of the city.
In the peripheral part of the city, only four regions are accessible, while others have low public transport routes accessibility. The public transport network in areas that were newly connected to the boundaries of the city from 1999-2000, and features the lowest development and fails to meet the inhabitants' needs.

Population density has an impact on density and the development of the public transport routes, or a district that has better accessibility to the public transport and is more attractive to people who choose where to live.

Table 1 provides a comparison of population density of the district in question with the accessibility of public transport routes. Population density and public transport accessibility were compared in the areas of districts, excluding green areas. This table also shows a clear (above-mentioned) dependence; only three districts of Vilnius are different from others: Valakupiai, Gariūnai and Verkiai. Valakupiai and Verkiai districts are the largest and most attractive recreation areas of the city; thus, even when the number of permanent inhabitants is low these districts have a great need for public transport, and which is necessary not just for the inhabitants, but also for visitors to these regions.

Gariūnai district, which has a low number of permanent inhabitants, and the market place of Gariūnai attract a lot of visitors and have about 7,000 work places, which result in a well-formed network of public transport.

\section{Changes in public transport accessibility in differ- ent areas of the city}

In 1998-2002, 6 new districts were annexed to the territory of Vilnius: Traku Voké, Vaidotai, Gureliai, Grigiškès, Medžiakalnis and Tarandè. In addition, the areas of Santariškès, Verkiai, Dvarčionys, Naujoji Vilnia, Pavilnys, Kuprijoniškès and Užusienis have also expanded on account of the growth of Vilnius' territory.

Urban public transport has had to be adjusted to the expanded boundaries of the city. The number of buses and trolleybuses was increased and old public transport routes were prolonged to reach the above-mentioned districts.

From 1998-2004, public transport routes accessibility to the districts of Vilnius and its suburbs has been on the increase (Fig 3). During the analyzed period, public transport accessibility has not become worse in any of the districts. In taking account of the location of the districts in the structure of the city, it is seen that in the central part public transport accessibility has been stable since 1998, with the exception of the Naujininkai district in which public transport route accessibility has increased by $8 \%$ (Table 2).

The greatest change in public transport route accessibility was observed in the peripheral part of the city, in which an accessibility of $23 \%$ to districts by public transport increased by more than $10 \%$. This is most clearly seen in the rise of accessibility of public transport routes in the districts of Riešè (30\%), A. Paneriai $(11 \%)$, and Pagiriai $(17 \%)$. The development of the public transport network in the Rieše district was influenced by the formation of new dwelling-house areas. 
The Pagiriai district was connected to the territory of Vilnius. The main reason for increased accessibility to the public transport routes in Vilnius' peripheral area is the expanded territory of the city. Minimal accessibility to public transport had to be ensured in the areas that were newly connected to the city. Thus, these districts became more attractive to Vilnius' inhabitants.

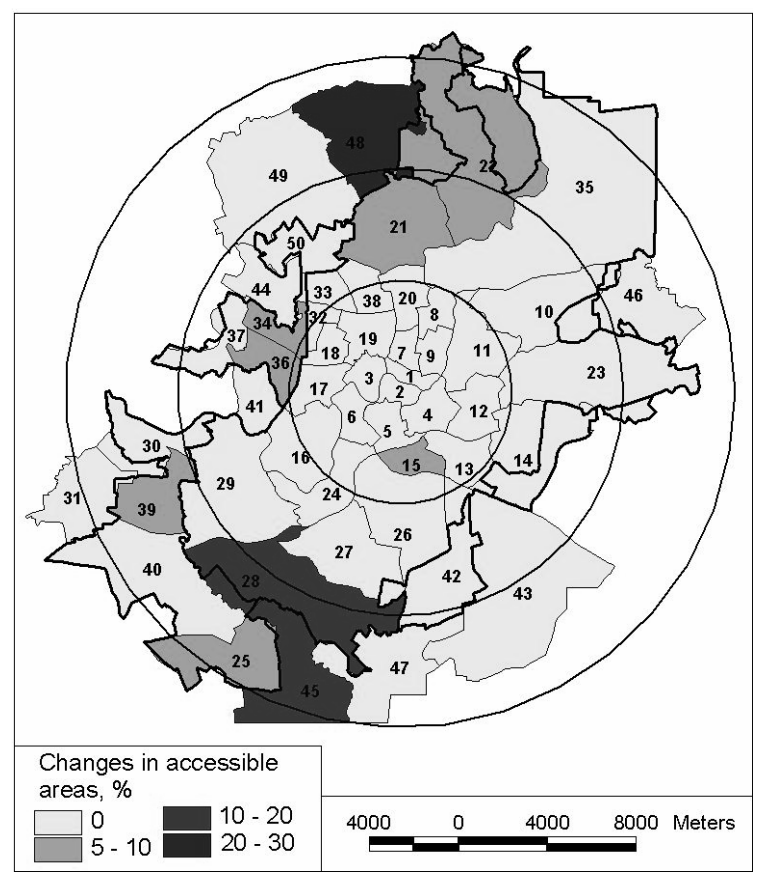

Fig 3. Changes in the accessibility of the public transport in 1998-2004
In spite of the growing level of public transport services in Vilnius, the number of trips by this transport mode has been continuously decreasing. Since 1990, trips by public transport accounted for $47,8 \%$ of all trips by motor vehicles, and until 2005 the percentage of such trips has become even lower. In aiming at the stability of the number of trips by public transport, the public transport system should be controlled so that the service is rendered in an optimal way $[15,16]$.

\section{Dependence of the housing price on accessibility to the public transport routes in districts}

Accessibility of public transport routes is only one of the indicators that have an impact on the quality of public transport services; and frequency of the public transport trips is another important indicator [17].

With regard to these two factors, accessibility to public transport routes during rush hours is better than that during daytime hours, as the number of public transport routes during rush hours is higher due to supplementary routes, which serve passengers only during rush hours, while at other times their schedule is scarce. Thus, these two factors become integral and in further studies the interaction of these two factors will be taken into consideration. Accessibility to public transport is also among factors that have influence on the choice of a dwelling place and on the housing price.

A survey of the situation of dwelling stocks in Vilnius, found that over $79 \%$ are flats in an apartment building. By taking account of a social group's travelling public transport needs, it was found that the housing prices of the district in question is considered to be on average, the price

Table 2. Changes in public transport accessibility depending on distribution in the city from 1998-2004

\begin{tabular}{|c|c|c|c|c|c|}
\hline \multicolumn{6}{|c|}{ District distribution in cities and towns } \\
\hline \multicolumn{2}{|c|}{ Up to $5 \mathrm{~km}$} & \multicolumn{2}{|c|}{$5-10 \mathrm{~km}$} & \multicolumn{2}{|c|}{$10-15 \mathrm{~km}$} \\
\hline Name & $\%$ & Name & $\%$ & Name & $\%$ \\
\hline Centras II & 0 & Ž. Paneriai & 0 & Nemėžis & 0 \\
\hline Centras I & 0 & Justiniškès & 0 & Avižieniai & 0 \\
\hline Senamiestis & 0 & Lazdynai & 9 & Grigiškès & 0 \\
\hline Naujamiestis & 0 & Kirtimai & 2 & Galgiai & 0 \\
\hline Žvėrynas & 0 & Pašilaičiai & 0 & Riešè & 30 \\
\hline Šnipiškès & 0 & Pilaitè & 6 & Gureliai & 7 \\
\hline Žirmūnai II & 0 & Pilaitė II & 6 & Verkiai & 10 \\
\hline Vilkpèdè & 0 & Pavilnys & 3 & Juodšiliai & 2 \\
\hline Naujininkai & 8 & Salotė & 0 & Valakupiai & 1 \\
\hline Šeškinė & 0 & Dvarčionys & 0 & Pagiriai & 17 \\
\hline Belmontas & 0 & Buivydiškès & 0 & Trakų Vokè & 4 \\
\hline Viršuliškès & 1 & Tarandè & 0 & Vaidotai & 6 \\
\hline Karoliniškès & 0 & Užusienis & 1 & Lentvaris & 0 \\
\hline Antakalnis & 0 & Santariškès & 7 & & \\
\hline Rasos & 0 & Medžiakalnis & 0 & & \\
\hline Žirmūnai & 0 & Kuprijoniškès & 0 & & \\
\hline Baltupiai & 0 & Naujoji Vilnia & 0 & & \\
\hline Fabijoniškès & 0 & Gariūnai & 3 & & \\
\hline & & A. Paneriai & 11 & & \\
\hline
\end{tabular}


of 1 square metre in 1-3 room apartments in not new houses. This makes up $89,6 \%$ of all Vilnius' flats, while others make up $10,4 \%$ and 4 or more roomapartments. In these flats live $10,4 \%$ inhabitance with a higher income, but of which less are using public transport [18, 19]. Therefore, the chosen price is due to the fact that the quality and accessibility of the public transport system is most relative to the group of inhabitants that have low or average incomes.

The exploitation of the dwelling relates to stock dwellings filtration. It is dwelling changes to another quality, which depends on the size of the inhabitants' income. For that reason some of Vilnius districts have become prestigious with higher dwelling prices just because of the living place [20]. The spread of the housing prices in Vilnius districts (Fig 4) corresponds to the city structure, where the highest housing prices are observed in the central parts and they decline as one goes further away from the centre. In Vilnius, besides the central part, high housing prices are also observed in the north, ie where Verkiai and Paviniai regional parks are located. The housing prices of three districts, Medžiakalnis, Gariūnai and Užusienis, have not been provided because industrial and commercial buildings prevail in these districts.

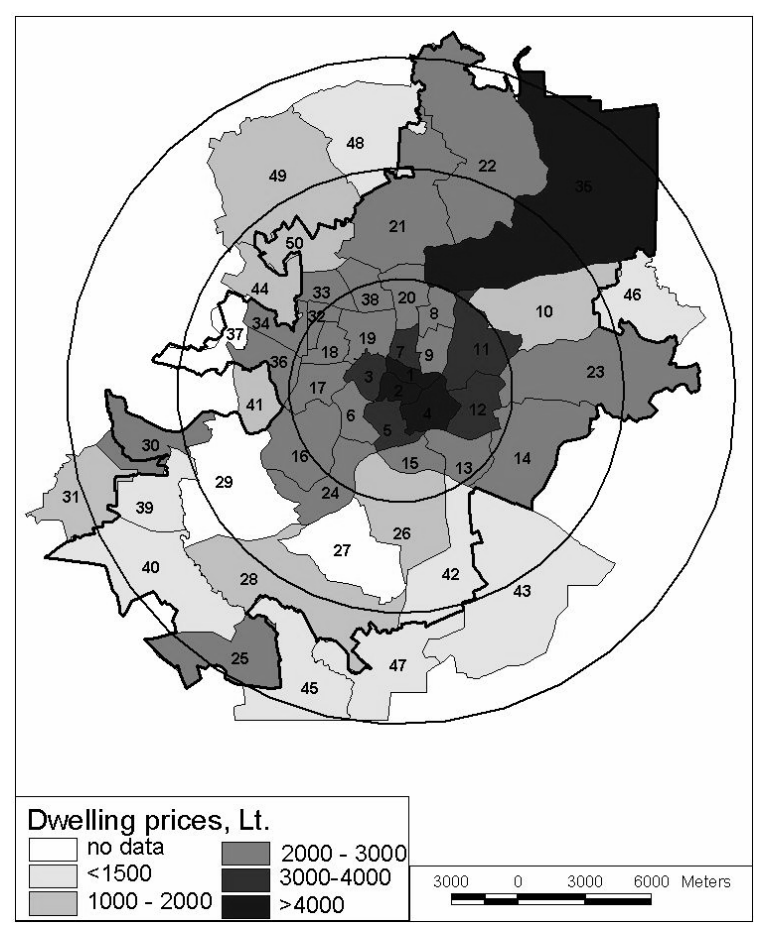

Fig 4. Dispersion of housing prices in Vilnius in 2004

Two districts that have been singled out are Grigiškès and Vaidotai; for a long time these districts were residential and only in 1999 they were connected to Vilnius and that fact resulted in higher housing prices. One of the most expensive districts is Valakupiai district. It is a prestigious district situated at the bend of the Neris river, it is mostly built up with private dwelling houses and its green areas account for $87 \%$ (mostly by Verkiai Regional Park).
For the purpose of identifying public transport service levels and its influence on housing prices, an analysis of indicators by applying Statgraphics software was done, and which describes social and public transport in Vilnius' districts. These indicators can be presented in four groups:

1. Social indicator's group, such as population density and working place density;

2. Distance to the centre of the city, which is the key geographical indicator;

3. Urbanisation indicator's group, showing the percentage of the territory covered by green areas and built-up areas;

4. Indicator's group of public transport services, ie route density and their accessibility.

All analysed data was collected in 45 districts of Vilnius and describe the situation in 2004. Užusienis, Gariūnai and Medžiakalnis districts were excluded because of the lack of information, and two districts were excluded because of their particularities, namely Verkiai and Valakupiai. The output model shows results of the fitting a multiple-linear regression model and describes the relationship between a housing price and 4 independent variables. There is a statistically significant relationship between the variables at the $99 \%$ confidence level. The R-Squared statistic indicates that the model, as fitted, explains $82 \%$ of the variability in housing prices. The $\mathrm{P}$-value is less than 0,10 , and that term is statistically significant at the $90 \%$ confidence level.

$$
H P=2433,8-5,4 P D-0,2 D+11,9 D J+14,6 A,
$$

where $H P$ - housing price, is in Litas (Lt); $P D$ - population density, inhab/1 $\mathrm{km}^{2} ; D$ - distance to the centre of the city, km; $D J$ - density of work places, work plc $/ 1 \mathrm{~km}^{2} ; A-$ accessibility to public transport, $\%$.

The dependence of housing prices and density of the work places and accessibility to public transport in the above formula 1, reveals that for the social group in question, ie low and medium income inhabitants of the city, the main factors when choosing housing is a dispersion of work places and access to public transport. The dependence of housing prices and density of work places can be explained by high housing prices in the centre of Vilnius where there is a concentration of work places. Reverse dependence of the housing price on the distance to the town centre has the same impact on this social group but not to the same extent as the accessibility to the public transport or work place density.

\section{Conclusions}

1. The analysis of Vilnius' public transport network has been divided into 50 transport districts within the boundaries of the city as accepted in the General Plan. In their turn, transport districts are attributed to three areas of the city: central, medial and peripheral. Based on the studies carried out by the Department of Urban Engineering and on this analysis, it has been established that the best public transport services should be maintained in the medial part, and other parts should be guaranteed mini- 
mal service, while in the central part, trips on foot should be made, and in peripheral parts - by car.

2. The studies that were carried out and their analysis have revealed that the public transport network of Vilnius is well developed with regard to accessibility. From 1998-2004, the accessibility of public transport has increased on average by $1,28 \%$ per year. During the period in question, public transport accessibility of not any transport district decreased, and in Riešè it increased by $30 \%$.

3. For public transport passengers, it is not important which carrier renders services as passengers care for the quality of services. To assure quality, it is necessary to rationally use and develop the network of public transport routes and the frequency of services as well as combine the above-named so that services rendered by public transport are optimal. Carriers should be chosen by arranging tenders, as this would strengthen competition and improve the quality of services, and, besides, this would be more feasible to the relations of carriers and the municipality.

4. Our research confirms that there exist dependences between density of population, density of work places, distance to the city centre and accessibility to public transport with dwelling prices. This proposition is very important for low and medium income inhabitant social group. This group of inhabitants accounts for the greatest number of passengers using public transport, and which has great influence on the choice of dwelling place as well as dwelling price.

\section{References}

1. Hensher, D. A. and Ton, T. A transportation, land use and environmental strategy impact simulator for urban areas. Transportation, 29(4), 2002, p. 439-457.

2. Herala, N. Regulating traffic with land use planning. International Journal of Sustainable Development, 11(2), 2003, p. 91-102.

3. Hine, J. and Mitchell, F. The role of transport in social exclusion in urban Scotland. Edinburgh: Scottish Executive Central research unit, 2001. 144 p.

4. Hine, J. and Mitchell, F. Transport disadvantage and social exclusion. Aldershot: Ashgate Publishing, 2003. $162 \mathrm{p}$.

5. Mackett, R. L. Why do people use their cars for short trips? Transportation, 30(3), 2003, p. 329-349.
6. Mackett, R. L. Policies to attract drives out of their cars for short trips. Transport Policy, 8(4), 2001, p. 295-306.

7. Gibbons, E. and O'Mahony, M.Transport policy prioritization for Dublin. Transportation, 27(2), 2000, p. 165178.

8. Steierwald, G. Stadtverkehrsplanung. Heidelberg: Springer Verlag, 2005. 829 p.

9. Oppenheim, N. Urban Travel Demand Modeling. New York: John Wiley \& Sons, 1995. 480 p.

10. Transportation Indicators of Economic Growth. The National Academy of Sciences, 2001. 58 p.

11. FRAMEWORK 5 EV/RD/11024/LV/VGTU. PORTAL. Promotion of Results in Transport Research and Learning.

12. LR Technical regulation STR2.06.01: 1999. Communication systems of towns, small towns and villages (STR 2.06.01: 1999. Miestų, miestelių ir kaimų susisiekimo sistemos). Vilnius, 1999. 48 p. (in Lithuanian).

13. Juskevicius, P. Planning of cities ' communication systems (Miestu susisiekimo sistemu planavimas). Vilnius: Technika, 1995. 212 p. (in Lithuanian).

14. Donchenko, V. and Kazmin, D. Restraining car use to achieve safety and sustainability of the transport system within major city's center. In: Proceedings of VI International Conference "Traffic Safety Management for Big Cities". St. Petersburg: Grand-Technology, 2004, p. $78-81$.

15. Obelenis, V. Work conditions and health for transport workers (Transportas: technologijos, ekonomika, aplinka, sveikata). Vilnius: Technika, 2003. 275 p. (in Lithuanian).

16. Perrot, J. Y. and Chantelus, G. Sponsorship for infrastructures and public employments. Experience of France (Infrastruktūrų ir komunalinių tarnybų finansavimas. Prancūziškoji patirtis. Prancūzijos infrastruktūrų, transporto ir būsto ministerija. Ekonomikos ir tarptautinių reikalų skyrius). Vilnius, 2001. 89 p. (in Lithuanian).

17. Wu, B. M. and Hine, J. P. A PTAL approach to measuring chantes in bus service accessibility. Transport Policy, 10(4), 2003, p. 307-320.

18. Jonaitis, V. and Naimaviciene J. Analysis of housing sector in Lithuania. International Journal of Strategic Property Management, 7(4), 2003, p. 172-182.

19. Jonaitis, V. and Naimaviciene J. Social and regional aspects of housing situation in Lithuania. International Journal of Strategic Property Management, 8(4), 2004, p. 231-239.

20. Auksciunas, V. The development peculiarities of the housing market in Lithuania. Journal of Civil Engineering and Management, 8, Suppl 2, 2002, p. 103-107 (in Lithuanian).

\section{PĖSČIŲJU ATSTUMO IKI VISUOMENINIO TRANSPORTO MARŠRUTŲ DINAMIKOS ANALIZE் IR JO ITAKA BÜSTO KAINOMS}

\section{R. Ušpalytė-Vitkūnienė, M. Burinskienė}

\section{Santrauka}

Prieinama visuomeninio transporto sistema yra esminis rodiklis, garantuojantis visiems žmonèms vienodas susisiekimo galimybes. Mokslininkų atlikti tyrimai parodé, kad menkas visuomeninio transporto pasiekiamumas labiausiai atsiliepia mažesnes pajamas gaunantiems ir vyresniojo amžiaus gyventojams. Šių grupių gyventojams sumažeja galimybès pasiekti švietimo įstaigas, darbo vietas ar sveikatos įstaigas. Kaip vienas iš visuomeninio transporto rodiklių šiai socialiniai gyventojų grupei aktualus ir visuomeninio transporto maršrutų pasiekiamumas. Jo analizė parodè, kad per šešerius metus nuo 1998 m. iki 2004 m. visuomeninio transporto pasiekiamumas Vilniuje vidutiniškai padidèdavo 1,28 \% per metus. 
Kaip parode ištirti gyventojų tankio, darbo vietų tankio, užstatytų teritorijų ir želdynų procento, visuomeninio transporto pasiekiamumo, maršrutų tankio tirtame rajone ir atstumo iki miesto centro rodikliai, visuomeninio transporto maršrutų pasiekiamumas daro nemažą ịtaką ir šiai socialinei grupei būdingo būsto kainoms.

Reikšminiai žodžiai: visuomeninis transportas, transporto sistema, pasiekiamumas, būsto kaina.

Rasa UŠPALYTÉ-VITKŪNIENE் is Assistant and PhD student in Dept of Urban Engineering at Vilnius Gediminas Technical University, Lithuania. She participated in 5 intern conferences. Her research interests include the development of urban transport system, public transport use and planning in urban transport system.

Marija BURINSKIENĖ. Professor, Dr, Head of Urban Engineering Dept and Director of Territorial Planning Research Institute of Vilnius Gediminas Technical University. She was project manager for more than 40 national projects from 1983, participated in more than 30 intern conferences and was involved in eight Framework 5 and 6 program projects. The main area of research interest is regularities and specificity of urban and regional sustainable development, development of urban transport system, as well as creation of decision-support system for implementing engineering solutions. 